Peter Alter

\title{
Herausforderer der Weltmacht. Das Deutsche Reich im britischen Urteil
}

\begin{abstract}
Anfang 1947 debattierte das Londoner Unterhaus über die politische und wirtschaftliche Situation im besiegten Deutschland. Dort hatte Großbritannien als Besatzungsmacht gemeinsam mit seinen Alliierten nach der deutschen Kapitulation Verpflichtungen übernommen, die sowohl seine wirtschaftliche Leistungsfähigkeit als auch die politische Gestaltungskraft seiner Politiker zu überfordern drohten. Die Debatte bot unversehens Gelegenheit für einen Rückblick auf die Geschichte eines Staates, der in der kurzen Zeitspanne seiner Existenz die Inselmacht zweimal herausgefordert hatte und nur unter Aufbietung aller ihrer Kräfte und im Bündnis mit anderen Mächten niedergeworfen werden konnte.
\end{abstract}

Die Frage, die sich den Abgeordneten in London stellte, war nicht sonderlich originell. Sie lag nahe und mußte geradezu zwangsläufig in jede öffentliche oder private Diskussion der britischen Deutschland- und Besatzungspolitik einfließen. Konnte und sollte die deprimierende politische Erfahrung mit dem Deutschen Reich nach dem Kriege den Siegermächten eine Leitlinie für zukunftsgerichtetes politisches Handeln in Deutschland sein? Sollte das nun durchweg negative Urteil über das Reich und seine kurze, wenngleich dramatische Geschichte die britische Haltung gegenüber den Deutschen beherrschen? „My fear is this“, meinte in der Debatte vom Februar 1947 der Labourpolitiker und spätere Minister Richard Stokes. „We have seen nationalism in Germany grow up and try to express itself in two forcible ways in the past two or three generations - first under Bismarck and then under Hitler. If we break up Germany again, the same thing will happen once more. The States will be at loggerheads with one another, there will be all kinds of intrigue with outside Powers, and the whole situation will become so charged in favour of Nationalism that, to use a rather bad electrical simile, all the positive poles will be off against the first suitable negative pole that appears, and there will be another wholesale row in Europe. 1 hope that the proposal to break up and dismember Germany will be entirely set aside and condemned for all time."

Stokes war ein Kritiker der britischen Deutschlandpolitik nach 1945, ein strikter Gegner aller Plāne, die auf eine Aufteilung des besiegten Reiches zielten. Doch das Bild, das er von Deutschland und seiner jüngsten Geschichte zeichnete, war nicht weniger schlicht wie seine Prognose über die künftige politische Entwicklung in Mittel-

' Hansard, Parl. Deb., H.C., 5. Serie, Bd. 432, Sp. 1832 f., 5. 2. 1947. 
europa im Falle einer Aufspaltung des Reiches. Dennoch ist das Bild nicht ganz untypisch für die britische Einstellung gegenüber Deutschland und seiner nationalstaatlichen Vergangenheit in den Jahren vor und nach 1945. Auf der akademischen Ebene ist dafür A.J.P. Taylors berühmt-berüchtigtes Buch The Course of German History, das im Jahr 1945 erstmals erschien und noch heute seine Leser und Käufer findet, das vielleicht bekannteste Beispiel. Das Urteil über Deutschland und seine jüngste Vergangenheit war in diesen Jahren verständlicherweise sehr stark von Emotionen bestimmt; es zeugte darüber hinaus von Unkenntnis der Verhältnisse in Deutschland und der deutschen Geschichte. Und es war vielfach geprägt von tradierten Klischees und Voreingenommenheit. Nach zwei großen militärischen Konfrontationen innerhalb eines Vierteljahrhunderts, nach Jahren der politischen, wirtschaftlichen und militärischen Rivalität und der nur gelegentlichen Kooperation, war nicht widerlegt, was in der Zeitschrift Edinburgh Review 1909 in einem Beitrag über die deutsch-britischen Beziehungen zu lesen war: „Undoubtedly, one of the chief causes of estrangement is the Englishman's and the German's abysmal ignorance of one another. ${ }^{\text {“2 }}$ Selbst noch vor wenigen Jahren charakterisierte der Journalist John Mander die deutsch-britischen Beziehungen als ,a tale of mutual misunderstanding “3. Der Topos von der gegenseitigen Unkenntnis war zur Konstante im Urteil des einen über den anderen geworden.

Natürlich ist die hier zitierte Aussage des heute vergessenen Politikers Richard Stokes, über dessen Vertrautheit mit der Geschichte des Deutschen Reiches nichts bekannt ist, letztlich nur ein britisches Urteil unter vielen. Es braucht nicht eigens betont zu werden, daß es das britische Urteil über Deutschland gar nicht gibt, auch nicht geben kann angesichts einer historischen Epoche, in der Deutschland binnen eines Dreivierteljahrhunderts viermal seinen Charakter mehr oder weniger tiefgreifend veränderte. Aus britischer Sicht gab es zwar seit 1871 so etwas wie ein „ewiges“ Deutschland, doch worin die Konstanz, der sich nicht verändernde Kern Deutschlands, des deutschen Nationalstaates und der Deutschen letzten Endes bestand, entzog sich einer genauen Definition. Auf den ersten Blick zumindest hatten das Bismarckreich, das Wilhelminische Deutschland, die Weimarer Republik und schließlich das sogenannte Dritte Reich der Nationalsozialisten aus britischer Sicht manches gemein.

Darüber hinaus gab und gibt es in einem freien Land wie dem Vereinigten Königreich ein ungemein breites Meinungsspektrum. Dadurch werden Verallgemeinerungen über Haltungen, Einstellungen, Vorurteile und Urteile der Briten außerordentlich erschwert, ja geradezu unmöglich gemacht. Das offizielle oder offiziöse Urteil über das Deutsche Reich in bestimmten Phasen seiner historischen Existenz, d.h. das Urteil der politischen Elite Großbritanniens, brauchte und braucht nicht notwendigerweise mit dem „britischen“ Urteil über bzw. der „britischen“ Einstellung zu Deutschland identisch zu sein. Im Gegenteil: Oft ist das nichtoffizielle Urteil über Deutschland bzw. sind die Einstellungen von Persönlichkeiten außerhalb des relativ kleinen Kreises von Politik, hoher Beamtenschaft und Regierung im Zeitraum 1871-1945 wesent-

2 Anonym, Anglo-German Relations, in: Edinburgh Review 210 (1909) 450.

${ }^{3}$ Jobn Mander, Our German Cousins. Anglo-German Relations in the Nineteenth and Twentieth Centuries (London 1974) 15. 
lich differenzierter, informierter und interessanter als das sogenannte offizielle Urteil, die Ansichten der „official mind“.

Die öffentliche Meinung Großbritanniens, wie sie sich vor allem seit der Jahrhundertwende beispielsweise in der neuen Massenpresse niederschlug, mochte vielfach in einer vergröberten und holzschnittartigen Version die Haltung der Regierung in Whitehall zum Deutschen Reich und seiner Politik spiegeln. Aber das Urteil des britischen Musikfreundes (um nur ein Beispiel zu nennen) über „das Land der Musik" hatte damit im späten 19. und im 20. Jahrhundert wenig zu tun. Auch dem Urteil und der Einstellung des einzelnen britischen Wissenschaftlers über und zu Deutschland, besonders in den Jahren zwischen 1870 und 1914, lagen völlig andere Kriterien und Maßstäbe zugrunde als denen des Politikers oder hohen Beamten im Foreign Office 4 Gleiches mag für den Industriellen und Geschäftsmann in Birmingham oder Manchester gegolten haben oder für den Bankier in der Londoner City. Und die britischen Monarchen wie auch die Aristokratie, ein letztes Beispiel, mochten zwar verwandtschaftliche Beziehungen zu deutschen Fürstenhäusern haben, die ihre Haltung zu Deutschland positiv oder auch negativ beeinflußte, doch die Anziehungskraft von Paris und Südfrankreich war für sie (Königin Viktoria einmal ausgenommen) unvergleichlich größer als diejenige Berlins oder Bayerns. Andererseits stieß das vermeintlich dekadente, republikanische Frankreich des späten 19. und frühen 20. Jahrhunderts bei der britischen Aristokratie, nicht bei Eduard VII., aber auch auf Vorbehalte, während es neben dem Berlin der Hohenzollern eben auch die Höfe in Braunschweig, Darmstadt, Dresden oder Coburg gab.

Es ist folglich nur korrekt und billig von britischen Urteilen über das Deutsche Reich, seine Politik, Diplomatie, Wirtschaft und Gesellschaft zu sprechen. Davon läßt sich für die Lebensspanne des ersten deutschen Nationalstaates eine geradezu erdrükkende Fülle zitieren ${ }^{5}$. In ihrer Gesamtheit vermitteln die Urteile den Eindruck außerordentlicher Heterogenität, zumal sie sich auf ganz unterschiedliche Aspekte der Lebenswirklichkeit und Politik in Deutschland und auf unterschiedliche Phasen von dessen Geschichte beziehen. $\mathrm{Zu}$ bedenken ist auch, daß Urteile über die Verhältnisse anderswo häufig einen bestimmten Zweck verfolgen. Sie zielen nicht auf eine zutref-

4 Thomas Kleinknecht, Die Gründung des Deutschen Reiches 1870/71 aus der Sicht des britischen Gelehrtenliberalismus, in: Bernd-Jürgen Wendt (Hrsg.), Das britische Deutschlandbild im Wandel des 19. und 20. Jahrhunderts (Bochum 1984) 81-102; Peter Alter, Science and the AngloGerman Antagonism, in: T.R. Gourvish, Alan O'Day (Hrsg.), Later Victorian Britain, 1867-1900 (Basingstoke 1988) 271-290; ders., Deutschland als Vorbild britischer Wissenschaftsplanung um die Jahrhundertwende, in: Adolf $M$. Birke, Lothar Kettenacker (Hrsg.), Wettlauf in die Moderne. England und Deutschland seit der industriellen Revolution (München 1988) 51-69.

5 Beispiele finden sich in der Literatur zu den deutsch-britischen Beziehungen seit 1870/71, die mittlerweile recht umfangreich ist. Die im folgenden genannten Arbeiten enthalten Bibliographien der älteren Literatur: Paul M. Kennedy, The Rise of the Anglo-German Antagonism 18601914 (London 1980); Raymond J. Sontag, Germany and England. Background of Conflict, 18481894 (New York 1964); Klaus Hildebrand, Großbritannien und die deutsche Reichsgründung, in: Eberhard Kolb (Hrsg.), Europa und die Reichsgründung. Preußen-Deutschland in der Sicht der großen europäischen Māchte 1860-1880 (München 1980) 9-62; ders., „British Interests“ und „Pax Britannica“. Grundfragen englischer Außenpolitik im 19. und 20. Jahrhundert, in: Historische Zeitschrift 221 (1975) 623-639. 
fende Charakterisierung der Realität im anderen Land, sondern sind im Grunde Kritik an Zuständen im eigenen Land. Indem im anderen Land etwas gepriesen oder bemängelt wird, versucht der Urteilende, den Lauf der Dinge im eigenen Land zu beeinfluBen. Die Grenzen zwischen Information und Manipulation von Informationen verschwimmen. Im Bewußtsein dieses hinlänglich bekannten Sachverhaltes lassen sich dennoch drei verallgemeinernde und typisierende Beobachtungen zum britischen Urteil über das Deutsche Reich machen. Sie stützen sich im wesentlichen auf Aussagen der politischen Elite Großbritanniens. Ob auf diese Weise eine Annäherung an das „britische Urteil“ über das Deutsche Reich zwischen 1871 und 1945 gelingt, sei dahingestellt.

1. In der längerfristigen Perspektive lassen sich in britischen Urteilen über das Deutsche Reich ungeachtet aller sich dort vollziehenden politischen Umwälzungen und Brüche so etwas wie Konstanten aufzeigen, zählebige Stereotypen, Vorurteile, Bilder, Verhaltens- und Reaktionsmuster. Sie dominieren die Urteile und sind über Jahre und Jahrzehnte hinweg öffentlichkeitswirksam und meinungsbildend, vielfach bis heute. Das Schlagwort vom „Vierten Reich“, das 1990-91 im Zuge der deutschen Vereinigung durch die Gazetten Europas geisterte, fand beispielsweise in Großbritannien ein stärkeres Echo und wurde dort ernster genommen als anderswo ${ }^{6}$. Die Wurzeln des geläufigen britischen Urteils über das Deutsche Reich sind in der Reichsgründungszeit zu suchen. In den achtziger und neunziger Jahren des 19. Jahrhunderts wurde es um ein paar wichtige Elemente ergänzt. Um die Jahrhundertwende stand das „pattern" mehr oder weniger fest. Es löste ein Deutschlandbild ab, das, wie Wolfgang $\mathrm{J}$. Mommsen gezeigt hat ${ }^{\dagger}$, bis zur Reichsgründungszeit gegolten hatte und sich aus völlig anderen Komponenten zusammensetzte.

2. Das Urteil der britischen Eliten und der britischen Öffentlichkeit über Deutschland, seine Politik und Gesellschaft, oszillierte im Zeitraum 1871-1945 zwischen zwei Polen bzw. zwei Extremen. Dabei lassen sich zeitliche Phasen ausmachen, in denen beide Extreme gleichzeitig und gleichgewichtig nachzuweisen sind, und Phasen, in denen ein Extrem mehr oder weniger allein das Feld beherrscht. Das eine Extrem war auf der britischen Seite die Haltung, daß das Deutsche Reich ein willkommener Partner Großbritanniens sei, in der Politik, der Diplomatie, der Wirtschaft, im Handel, bei der Konsolidierung und Verteidigung des weltumspannenden Empire. Aus dieser Haltung resultierte ein positives, manchmal sogar unrealistisches und überschwengliches britisches Urteil über das Reich, seine Institutionen und führenden Persönlichkeiten. Das andere Extrem im Spektrum britischer Urteile über das Reich drückte sich in der Überzeugung aus, daß das Deutsche Reich ein Herausforderer, ja gefährlicher Rivale Großbritanniens sei, in der Außen- und Kolonialpolitik, auf militärischem

' Siehe dazu Richard Davy, Großbritannien und die Deutsche Frage, in: Europa-Archiv 45 (1990) 139-144; Güntber Heydemann, Partner oder Konkurrent? Das britische Deutschlandbild während des Wiedervereinigungsprozesses 1989-1991, in: Franz Bosbacb (Hrsg.), Feindbilder. Die Darstellung des Gegners in der politischen Publizistik des Mittelalters und der Neuzeit (Köln 1992) 201-234.

7 Wolfgang J. Mommsen, Two Centuries of Anglo-German Relations. A Reappraisal (London 1984) 15. Siehe auch Angela Scbwarz, Die Reise ins Dritte Reich. Britische Augenzeugen im nationalsozialistischen Deutschland (1933-39) (Göttingen 1993) 41. 
Gebiet (insbesondere der Flottenrüstung), in Wirtschaft, Handel und der Wissenschaft. Aus dieser, von Panikreaktionen nicht freien Einstellung heraus resultierte häufig ein überaus negatives, manchmal geradezu irrational anmutendes britisches $\mathrm{Ur}$ teil über das Reich, das praktisch seit seiner Gründung in Großbritannien als die stärkste europäische Kontinentalmacht eingeschätzt wurde, ein wirtschaftlicher und militärischer Gigant, der seinen Nachbarn das Fürchten zu lehren imstande war.

Die unfreundliche bis negative Einschātzung bedeutete jedoch nicht zwangslāufig, daß das Reich als europäische Kontinentalmacht in London auch als die größte Bedrohung für die weltpolitischen Interessen Großbritanniens angesehen wurde. Eine solche Bedrohung ging, besonders in den Jahrzehnten vor 1907, in britischer Sicht primär von Rußland aus und dann, nach dem Ersten Weltkrieg bis in die frühen dreißiger Jahre von der Sowjetunion ${ }^{8}$. Noch im späten 19. Jahrhundert galten Rußland und Frankreich für die Briten als „the two aggressive powers of the Continent ${ }^{\text {“99. }}$.

Im Grunde und überspitzt formuliert stellte das Reich in der britischen Perspektive bis zum Vorabend des Ersten Weltkrieges nur einen Störfaktor dar, der die Aufmerksamkeit der britischen Regierung von den wichtigen Problemen in Übersee zeitweise ablenken konnte. Das war lästig und bot Anlaß für heftige Irritationen im deutsch-britischen Verhältnis, so vor allem der Beginn des Schlachtflottenbaus seit 1897. Doch spätestens 1910 war den Experten klar, daß Großbritannien im Wettrüsten zur See die Oberhand behielt ${ }^{10}$. Solange die stabile Ordnung eines machtpolitisch ausbalancierten Staatensystems in Kontinentaleuropa nicht gefährdet war und Großbritannien freie Hand bei der Lösung kolonialer und innenpolitischer Probleme hatte, verhielt sich die britische Regierung neutral bis wohlwollend gegenüber den Geschehnissen in Deutschland und den außenpolitischen Aktionen der Berliner Regierung, wie rätselhaft sie den Briten auch manchmal erscheinen mochten. Das Reich konnte dann, wie in den siebziger und achtziger Jahren des 19. Jahrhunderts und den Jahren der Weimarer Republik, als Partner, ja sogar als potentieller Bundesgenosse gesehen werden. Nicht untypisch für die britische Haltung war, was der neue Außenminister Lord Lansdowne im November 1900 unmittelbar nach Amtsübernahme an den britischen Botschafter in Berlin schrieb: „I shall undertake the duties of my new office without I hope too many preconceived ideas, but I plead guilty to one - the idea that we should use every effort to maintain, and if we can to strengthen the good relations which at present exist between the Queen's Government and that of the Emperor."

3. Das seit dem frühen 19. Jahrhundert in der britischen Außenpolitik weitgehend geltende Prinzip der politischen und militärischen Non-Intervention oder der „intelligent inaction " auf dem europäischen Kontinent und die schon angesprochenen weltpolitischen Interessen Großbritanniens zogen eine merklich distanzierte Haltung ge-

${ }^{8}$ Gottfried Niedhart, Großbritannien und die Sowjetunion 1934-1939. Studien zur britischen Politik der Friedenssicherung zwischen den beiden Weltkriegen (München 1972).

' So der Außenminister Lord Stanley an den britischen Botschafter in Paris am 7. 8. 1866 (zit. in: Werner E. Mosse, The European Powers and the German Question 1848-1871 with special reference to England and Russia [Cambridge 1958] 249).

10 Robert K. Massie, Britain, Germany, and the Coming of the Great War (London 1992) $709 \mathrm{ff}$.

$"$ Zit. in: P.J.V. Rolo, Lansdowne, in: Keith M. Wilson (Hrsg.), British Foreign Secretaries and Foreign Policy: From Crimean War to First World War (London 1987) 159. 
genüber Deutschland und anderen kontinentaleuropäischen Staaten nach sich ${ }^{12}$. Disraelis Diktum von Großbritannien als „metropolis of a great maritime empire“ (Juni 1866) ${ }^{13}$ gab der weitverbreiteten Stimmung Ausdruck, daß sich das Inselreich nicht primär als europäische Macht, sondern als Weltmacht verstand, in Disraelis gern zitierten Worten: mehr als eine asiatische denn europäische Macht ${ }^{14}$. Diese distanzierte Haltung zu Kontinentaleuropa und seinen politischen Problemen findet sich im britischen Urteil über das Deutsche Reich wieder bzw. beeinflußt das Urteil: Es ist im Einzelfall oft oberflächlich, undifferenziert und beruht nur in seltenen Fällen auf eigener Anschauung und Kenntnis der Verhältnisse in Deutschland. „Uber Preußen“, hatte Bismarck schon während seiner Englandreise im Sommer 1862 spitz bemerkt, „wissen die englischen Minister weniger wie über Japan und die Mongolei" ${ }^{\text {"15. }}$.

Im Grunde, und wieder etwas pauschal aus der Vogelperspektive gesehen, hat es zwischen 1871 und 1945 nur zwei Phasen gegeben, in denen das Deutsche Reich von den Briten weniger distanziert wahrgenommen wurde und in denen seine innenpolitischen und sozialen Verhältnisse eingehender studiert wurden. Ob das britische Urteil über Deutschland dadurch in dieser Zeit realistischer oder zutreffender wurde, ist eine Frage, die auch im prüfenden Rückblick nur schwer zu entscheiden ist.

Die erste Phase einer intensiveren britischen Wahrnehmung Deutschlands waren die Jahre zwischen ca. 1885 und 1914. Die sich damals verstärkende Wahrnehmung des Reiches in Großbritannien steht im engen Zusammenhang mit der neuen politischen Herausforderung der Weltmacht durch eine europäische Kontinentalmacht. Die Kolonial- und Flottenpolitik des Reiches und die hinter ihr vermuteten weiterreichenden Strategien und Ambitionen Berlins erzwangen die Aufmerksamkeit Whitehalls. Doch die verstärkte Wahrnehmung des Reiches hing auch zusammen mit der in diesen Jahren geführten britischen Diskussion über den vermeintlichen Niedergang bzw. das Zurückfallen von Großbritanniens Wirtschaft und Wissenschaft gerade im Vergleich mit dem rasch zur modemen Industriemacht aufsteigenden Reich. Der Publizist Ernest Williams leitete seine berühmte Schrift von 1896 Made in Germany mit den schockierenden Sätzen ein: „The Industrial Supremacy of Great Britain has been long an axiomatic commonplace; and it is fast turning into a myth ... The industrial glory of England is departing, and England does not know it." $" 16$

12 Siehe für die sechziger Jahre des 19. Jahrhunderts Peter Alter, Weltmacht auf Distanz. Britische Außenpolitik 1860-1870, in: Eberhard Kolb (Hrsg.), Europa vor dem Krieg von 1870. Mächtekonstellation - Konfliktfelder - Kriegsausbruch (München 1987) 71-91; allgemein auch Muriel E. Chamberlain, ,Pax Britannica'? British Foreign Policy 1789-1914 (London 1988) und Hildebrand, „British Interests“ und „Pax Britannica“.

${ }^{13}$ Zit. in: Hildebrand, Großbritannien und die deutsche Reichsgründung, 24.

${ }^{14}$ So in einer Rede im Juni 1866 (William F. Monypenny, George E. Buckle [Hrsg.], The Life of Benjamin Disraeli, Earl of Beaconsfield, Bd. 2: 1860-1881 [London 1929] 201).

15 Brief Bismarcks an seine Frau vom 5. 7. 1862, in: Otto von Bismarck, Die gesammelten Werke, Bd. 14/II (Berlin 1933, Neudr. Nendeln 1972) 599. Siehe Lothar Gall, Bismarck und England, in: Paul Kluke, Peter Alter (Hrsg.), Die deutsch-britischen Beziehungen im Laufe der Jahrhunderte (Stuttgart 1978) 46-59.

${ }^{16}$ Ernest E. Williams, „Made in Germany“ (London 1896) 1; Ross J.S. Hoffman nannte Williams' Buch ,the most famous and sensational piece of alarmist literature ..., a trumpet blast to awaken 
Den informierten Zeitgenossen war mehr oder weniger klar, daß die beträchtlichen Verschiebungen im Gefüge der Weltwirtschaft seit dem ausgehenden 19. Jahrhundert zu einem erheblichen Teil mit der mangelhaften Entwicklung neuer wissenschaftsabhāngiger und wachstumsintensiver Industrien in Großbritannien zusammenhingen. Als Paradebeispiel dafür wurde meist die Teerfarbenindustrie angeführt, die großindustrielle Herstellung synthetischer Farben, die in Deutschland die Grundlage für den erstaunlichen Aufstieg seiner chemischen Industrie bildete. Im Gegensatz zur britischen Regierung, so schrieb die Tageszeitung The Daily Telegraph 1906, habe die deutsche Regierung in der Vergangenheit alles getan, um die chemische Forschung und die Entfaltung der chemischen Industrie zu fördern. Und die Deutschen seien dafür belohnt worden. Wörtlich hieß es: „They have created a colossal trade, much of which might have been ours. ${ }^{17}$ Der Bedrohung vitaler britischer Interessen durch die deutsche Politik, die deutsche Militärmacht, die deutsche Wirtschaft und die anwendungsorientierte deutsche Wissenschaft in den Jahren und Jahrzehnten vor 1914 konnte Großbritannien nur begegnen, so schien es zeitgenössischen Beobachtern, indem es deutsche "scientific methods“ (was immer man darunter verstand) gründlich studierte und weitgehend übernahm. Dem Reich wurde von den Briten die Qualitāt eines partiell modernen Staates zugestanden, der anderen Gesellschaften den Weg in die Zukunft zeigte ${ }^{18}$.

Durch die Arbeiten von Peter Hennock ist uns auch bekannt, welch großer Wertschätzung sich neben der Wissenschaft in Deutschland auch das deutsche System der Sozialversicherung in Großbritannien erfreute ${ }^{19}$. Das Studium der deutschen Sozialpolitik, das den späteren liberalen Premierminister David Lloyd George im August 1908 nach Deutschland führte, setzte ebenfalls in den Jahren vor dem Ersten Weltkrieg ein. Es unterstreicht die Bedeutung, die das Reich in dieser Zeit für Großbritannien als Modell hatte - als Modell, das man nicht unbedingt kopieren mußte, doch welches das eingehende Studium bei der Vorbereitung von Reformen lohnte. Der

\section{Fortsetzung Fußnote von Seite 164}

his countrymen" (Great Britain and the German Trade Rivalry, 1875-1914 [Philadelphia und London 1933] 246). Dazu neben Martin J. Wiener, English Culture and the Decline of the Industrial Spirit, 1850-1980 (Cambridge 1981) jetzt die Studie von William D. Rubinstein, Capitalism, Culture, and Decline in Britain, 1750-1900 (London 1993).

17 The Daily Telegraph, 19. 2. 1906.

18 Vgl. dazu u.a. Peter Alter, Wissenschaft, Staat, Mãzene. Anfänge moderner Wissenschaftspolitik in Großbritannien 1850-1920 (Stuttgart 1982) bes. 90-156.

19 Siehe vor allem E.P. Hennock, British Social Reform and German Precedents. The Case of Social Insurance 1880-1914 (Oxford 1987); ders., Arbeiterunfallentschādigung und Arbeiterunfallversicherung: Die britische Sozialreform und das Beispiel Bismarcks, in: Geschichte und Gesellschaft 11 (1985) 19-36; ders., Die Ursprünge der staatlichen Sozialversicherung in Großbritannien und das deutsche Beispiel 1880-1914, in: Wolfgang J. Mommsen, Wolfgang Mock (Hrsg.), Die Entstehung des Wohlfahrtsstaates in Großbritannien und Deutschland 1850-1950 (Stuttgart 1982) 92-114; siehe auch Gerbard A. Ritter, Sozialversicherung in Deutschland und England. Entstehung und Grundzüge im Vergleich (München 1983) bes. 150-169. Die Vorbildfunktion der deutschen Technischen Hochschulen in England untersucht E.P. Hennock in: Technological Education in England, 1850-1926: the Uses of a German Model, in: History of Education 19 (1990) 299-331. 
Astronom Norman Lockyer erklärte Anfang 1907 auf einer öffentlichen Versammlung: „Germany is strengthening its universities just as thoroughly as it is strengthening its Fleet, a reminder that we ought to be able to compete with other nations in the preparation and equipment for industrial progress, as well as for war." ${ }^{\text {"20 }}$ Winston Churchill appellierte im Dezember 1908 an Premierminister Asquith: „Germany ... has managed to establish tolerable basic conditions for her people. She is organised not only for war but for peace. We are organised for nothing except politics. The minister who will apply to this country the successful experience of Germany in social organisation may or may not be supported at the polls, but he will at least have left a memorial ... Thrust a big slice of Bismarckianism over the whole underside of our industrial system, and await the consequences whatever they may be with a good conscience. ${ }^{21}$ Geradezu symptomatisch ist, was der Geologe und ehemalige Präsident der Royal Society of London im Rückblick auf die Jahre vor 1914 schrieb: „The example of that country [ = Deutschland] was often cited here, and contrasted with the unsympathetic attitude and stingy support of our authorities, much to the surprise and annoyance of the permanent officials of the Treasury, who seemed rather to think that their grants to science were remarkably liberal. I remember an occasion when I had to go to the Treasury about a matter connected with the Geological Survey. The official on whom I called was one of the heads of the Department... He began the interview by saying that he would be glad to hear me, but begged that the example of Germany might not be mentioned. “22

Die zweite Phase einer intensiven Wahrnehmung Deutschlands begann in Großbritannien 1933 mit der sogenannten Machtergreifung der Nationalsozialisten. Wie Brigitte Granzow, Rolf Kieser und Francis Carsten in ihren Arbeiten zum Aufstieg des Nationalsozialismus und dessen Spiegelung in der britischen Presse gezeigt haben ${ }^{23}$, standen der britischen Öffentlichkeit und Regierung seit den frühen dreißiger Jahren für ihre Urteilsbildung eine Vielzahl von Informationen über Hitler und seine Bewegung zur Verfügung. Darunter waren erstaunliche Einsichten in den wahren Charakter und die Gefährlichkeit Hitlers und des Nationalsozialismus. Granzow, Kieser und Carsten haben aber auch gezeigt, daß bei den meisten Briten erst lange nach der

${ }^{20}$ Bericht über die 1. Jahresversammlung der British Science Guild, abgedr. in: Nature 75 (190607) 327

${ }^{21}$ Zit. in: Ritter, Sozialversicherung, 161.

22 Archibald Geikie, Retrospect and Prospect, in: Nature 104 (1919-20) 196. Vgl. dazu auch Manfred Messerschmidt, Deutschland in englischer Sicht: Die Wandlungen des Deutschlandbildes in der englischen Geschichtsschreibung (Düsseldorf 1955), und Günter Hollenberg, Englisches Interesse am Kaiserreich. Die Attraktivität Preußen-Deutschlands für konservative und liberale Kreise in Großsbritannien 1860-1914 (Wiesbaden 1974).

${ }_{23}$ Brigitte Granzow, A Mirror of Nazism. British Opinion and the Emergence of Hitler 19291933 (London 1964); Rolf Kieser, Englands Appeasementpolitik und der Aufstieg des Dritten Reiches im Spiegel der britischen Presse (1933-1939). Ein Beitrag zur Vorgeschichte des Zweiten Weltkriegs (phil. Diss. Winterthur 1964); Francis L. Carsten, Adolf Hitler im Urteil des Auslandes - in britischer Sicht, in: Wolfgang Treue, Jürgen Scbmädeke (Hrsg.), Deutschland 1933. Machtzerfall der Demokratie und nationalsozialistische „Machtergreifung“(Berlin 1984) 97-118. Hinzuweisen ist auch auf Howard B. Gotlieb, England and the Nature of the Nazi Regime. A Critical Assessment of British Opinion, 1933-1938 (phil. Diss. Oxford 1953). 
Machtübernahme der Nationalsozialisten ein Prozeß einsetzte, in dessen Verlauf die einzelnen Informationen über Teilaspekte zu einem kohärenten Bild und Urteil über das nationalsozialistische Deutschland zusammengesetzt wurden. Dabei zogen die Konsolidierungsjahre der nationalsozialistischen Herrschaft in Deutschland ein Maximum an britischer Zustimmung und positiver Bewertung auf sich, wenngleich die Maßstäbe für die Interpretation der Informationen und die Urteilsbildung noch weitgehend schwankten. Im Juli 1933 schrieb der Pressezar Lord Rothermere in der Daily Mail: „I write from a new country on the map of Europe. Its name is Naziland ... I urge all British young men and women to study closely the progress of this Nazi regime in Germany. They must not be misled by the misrepresentations of its opponents ... The minor misdeeds of individual Nazis will be submerged by the immense benefits that the new regime is already bestowing upon Germany. ${ }^{\text {"24 }}$ Selbst der nüchterne Anthony Eden schrieb nach seiner Begegnung mit Hitler im Februar 1934: „Of one thing I am confident: the new Germany of Hitler and Goebbels is to be preferred to the old of Bülow. “25 Die Jahre 1934 und 1935 markieren den Höhepunkt von Sympathie und unkritischer Begeisterung für Hitler-Deutschland bei einem Teil der britischen Eliten und Bevölkerung ${ }^{26}$.

In der Mitte der dreißiger Jahre verlagerte sich das Schwergewicht des britischen Interesses an Nazi-Deutschland von inneren Aspekten des neuen Regimes auf dessen zunehmend bedrohlicher werdende außenpolitische Aktionen. Der etablierte Nationalsozialismus trat nach außen immer aggressiver und selbstsicherer auf. Die Wiedereinführung der allgemeinen Wehrpflicht im März 1935 und der Einmarsch der Reichswehr in das entmilitarisierte Rheinland nur ein Jahr später waren für die Briten Alarmsignale ${ }^{27}$. Aber seit 1935 beanspruchten auch andere Krisenherde die Aufmerksamkeit der britischen Regierung und Öffentlichkeit: der Überfall des faschistischen Italiens auf Abessinien, der Bürgerkrieg in Spanien und der chinesisch-japanische Konflikt, ganz abgesehen von den vorrangigen wirtschaftlichen, konstitutionellen und sozialen Problemen im eigenen Land. Die Vorgānge in und um Deutschland traten dahinter zurück. Mit dem „Anschluß“ Österreichs an das Reich 1938 und den Ereignissen um die Tschechoslowakei wandte sich das britische Interesse erneut dem nationalsozialistischen Deutschland $\mathrm{zu}^{28}$.

In dieser zweiten Phase einer intensiveren Deutschlandwahrnehmung wie auch po-

24 Schwarz, Reise, 64.

${ }^{25}$ Zit. in: Gottfried Niedhart, Zwischen negativem Deutschlandbild und Primat des Friedens: Großbritannien und der Beginn der nationalsozialistischen Herrschaft in Deutschland, in: Wolfgang Michalka (Hrsg.), Die nationalsozialistische Machtergreifung (Paderborn 1984) 278.

${ }_{26}$ Richard Griffiths, Fellow Travellers of the Right. British Enthusiasts for Nazi Germany, 19331939 (London 1980); Schwarz, Reise, 381-394.

27 Walter Bußmann, Maßstābe diplomatischer Urteilsbildung im Foreign Office wāhrend der Rheinlandkrise 1936, in: Lotbar Kettenacker u.a. (Hrsg.), Studien zur Geschichte Englands und der deutsch-britischen Beziehungen. Festschrift für Paul Kluke (München 1981) 263-280; Karl Robe (Hrsg.), Die Westmächte und das Dritte Reich 1933-1939 (Paderborn 1982).

28 Gustat Scbmidt, England in der Krise. Grundzüge und Grundlagen der britischen Appeasement-Politik (1930-1937) (Opladen 1981) 97-180; Bernd-Jürgen Wendt, München 1938. England zwischen Hitler und Preußen (Frankfurt/M. 1965). 
litischer und geistiger Auseinandersetzung mit Deutschland, im Jahrzehnt zwischen Weltwirtschaftskrise und Kriegsausbruch, stützte sich das britische Urteil über Deutschland wie noch nie zuvor auf eine überaus kundige und ausführliche Berichterstattung der überregionalen Presse und auf eine große Zahl von publizierten Erfahrungs- oder Augenzeugenberichten. Nach den Untersuchungen von Angela Schwarz erschienen zwischen 1933 und 1940 in Großbritannien fast 500 Buchpublikationen über das Deutschland Hitlers und seinen Weg in die Diktatur. Allein in den Jahren 1933/34 waren es 104 Titel, 1939 angesichts der unmittelbaren militärischen Bedrohung Großbritanniens sogar 123 Titel $^{29}$. An authentischen Informationen für ein fundiertes britisches Urteil über das „Dritte Reich“ bestand also wahrlich kein Mangel. $\mathrm{Zu}$ denen, die damals Deutschland besuchten, gehörte auch Winston Churchill. Zwar scheiterte im Sommer 1932 ein Zusammentreffen mit dem „Führer“ in München ${ }^{30}$, doch der Besuch war für Churchill auch Anlaß und Grundlage, drei Jahre später in einem hellsichtigen Artikel im Strand Magazine über „The Truth about Hitler" zu schreiben $^{31}$. Auf ihn ist noch einzugehen.

Vor und zwischen den beiden hier skizzierten Phasen einer intensiveren Wahrnehmung des Reiches in Großbritannien und einer möglicherweise fundierteren Beurteilung Deutschlands ist das britische Urteil, wie schon gesagt, im Grunde von Distanz, ja häufig sogar Gleichgültigkeit geprägt. Darin spiegelt sich das britische Desinteresse an den Geschehnissen in Mitteleuropa. Donald Watt sprach sogar einmal von Apathie in der britischen Haltung zum Reich ${ }^{32}$. Dabei schwangen im britischen Urteil schon im Umfeld der Reichsgründung ablehnende bis feindselige Untertöne mit. Disraelis Charakterisierung der Reichsgründung als „deutsche Revolution“ und seine eindringliche Warnung vor deren langfristigen Auswirkungen auf Großbritannien und das „Gleichgewicht der Macht" in Europa sind hinlänglich bekannt ${ }^{33}$, ebenso Gladstones entschiedene Ablehnung der deutschen Annexion Elsaß-Lothringens im Oktober 1870. "To wrench a million and a quarter of a people from the country to which they have belonged for some two centuries, and carry them over to another country of which they have been the almost hereditary enemies, is a proceeding not be justified in the eyes of the world and of posterity by any mere assertion of power, without even the attempt to show that security cannot be had by any other process. ${ }^{\text {"34 }}$ Gladstone beklagte hier öffentlich die Verletzung des Selbstbestimmungsrechts durch das gerade entstehende Reich und plädierte mit Nachdruck für den „westlichen“ Nationsbegriff, für den der politische Wille und nicht die Abstammung das entscheidende Kriterium

29 Angela Schwarz, In Großbritannien veröffentlichte Literatur über den Nationalsozialismus bzw. das nationalsozialistische Deutschland (1933-1945), in : Jahresbibliographie 1988. Bibliothek für Zeitgeschichte Stuttgart (Koblenz 1990) 539-569; dies, Reise, 57.

${ }_{30} \mathrm{Vgl}$. Churchills kurzen Bericht über seinen Deutschlandaufenthalt in: Winston S. Churchill, The Second World War, Bd. 1: The Gathering Storm (London ' 1971$) 75 \mathrm{f}$.

31 Winston Cburchill, The Truth about Hitler, in: Strand Magazine 90 (Nov. 1935) 10-21.

32 Donald C. Watt, Zwischen Apathie und Verständigung. Die Berichte der britischen Botschafter in Berlin, in: Das Parlament, Nr. 4/5 (29.1./5. 2. 1983).

${ }_{33}$ Hansard, Parl. Deb., H.C., 3. Serie, Bd. 204, 81 f. (9. 2. 1871).

34 W.E. Gladstone, Germany, France, and England, in: Edinburgh Review 132 (Oktober 1870), wieder abgedr. in: ders., Gleanings of Past Years, 1843-1878, Bd. 4 (London 1879) 241. 
für die Zugehörigkeit zu einer Nation ist. Der Hof, das Foreign Office und große Teile der britischen Öffentlichkeit mißbilligten ebenfalls die Annexion Elsaß-Lothringens ${ }^{35}$. Die Sympathien wandten sich dem geschlagenen und gedemütigten Frankreich zu. Im Juni schrieb die britische Schriftstellerin George Eliot an eine deutsche Bekannte: „I think you misconceive the state of English minds generally at the opening of the War. So far as our observation went, English sympathy was mainly on the German side. It was not till after the battle of Sedan, that there was any widely-spread feeling on behalf of the French." ${ }^{36}$ Das Urteil über Bismarck, für Königin Viktoria „the wicked man" ${ }^{37}$, und sein Werk war damit von der Entstehung des Reiches an mit Skepsis, ja Entrüstung behaftet. Das Aperçu des Diplomaten Henry Lytton Bulwer von Anfang 1871 traf die Stimmung in Großbritannien - es wirkte lange nach: „Europe has lost a mistress and got a master. ${ }^{\star 38}$

Durch die Begleitumstände der Reichsgründung war jedoch noch kein Keil in die Beziehungen Großbritanniens zu Deutschland getrieben, der die Zukunft auf Dauer belastet hätte. Von einer politischen Entfremdung zwischen London und Berlin konnte nicht die Rede sein, trotz aller Kritik an Bismarcks ,Junkerregiment“. Der Kronprinz Friedrich schien eine liberalere Zukunft zu garantieren. Im Grunde blieb das britische Urteil über das junge Reich bis in die neunziger Jahre hinein fair, wenn auch nicht frei von Befürchtungen über seinen künftigen Weg. „I am afraid the result will be“, schrieb Gladstone Anfang 1871, „that Germany, crowned with glory and confident in her strength, will start on her new career to encounter the difficulties of the future without the sympathies of Europe: which in my opinion no nation, not even we in our seagirt spot, can afford to lose. ${ }^{\text {"39 }}$ Die Historiographie hat immer wieder darauf hingewiesen, daß die Existenz eines geeinten deutschen Staates, dessen Regierung eine Politik der Stabilität und „Saturiertheit" verfolgte, keine Bedrohung für Großbritannien und seine vitalen Interessen in Europa und darüber hinaus darstellte. Im Gegenteil: Der junge deutsche Nationalstaat konnte unter dem Schirm der Pax Britannica durchaus die gleiche stabilisierende Funktion in Europa ausüben, die sich Großbritannien nach dem Wiener Kongreß vom vergrößerten Preußen und vom Deutschen Bund erhofft hatte. Es waren primär Frankreich und Rußland, später auch die Vereinigten Staaten, die London als weltpolitische Rivalen und potentielle Kontrahenten betrachtete.

So bestand zwischen der Politik Bismarcks, die auf Friedenserhalt in Europa abzielte, und den Zielen britischer Europapolitik zur Wahrung des Status quo eine sehr weitgehende Kongruenz. Dies schien auf längere Sicht Normalitāt und Kooperation in den Beziehungen beider Staaten zueinander zu garantieren. Der Außenminister

35 Vgl. dazu die gründliche Analyse von Thomas Schaarschmidt, Außenpolitik und öffentliche Meinung in Großbritannien wāhrend des deutsch-französischen Krieges von 1870/71 (Frankfurt/M. 1993).

${ }^{36}$ Zit. in: Güntber Blaicber, Das Deutschlandbild in der englischen Literatur (Darmstadt 1992) 157.

37 Zit. in: Hollenberg, Englisches Interesse, 19.

${ }^{38}$ Zit. in: Jobn Morley, The Life of William Ewart Gladstone, Bd. 2 (London 1903) 357. Vgl. auch Hollenberg, Englisches Interesse, 21.

39 Zit. in: Kleinknecht, Gründung, 93. 
und ehemalige Premierminister Lord Derby konnte im Juli 1875 mit Recht erklären, zwischen Großbritannien und dem Deutschen Reich gebe es keinen grundsätzlichen Interessenkonflikt ${ }^{40}$. Die Times beschrieb das britisch-deutsche Verhältnis im September 1876 mit folgenden Worten: „We have no jealousy of the new Empire. Within its own bounds we wish it every success. But we feel that an enormous power for good or evil has risen up somewhat suddenly in the midst of us, and we watch with interested attention for signs of its character and intentions." ${ }^{\text {i } 1}$

Der fast dramatisch zu nennende Umschlag vom letzten Endes wohlwollenden, leicht paternalistischen britischen Urteil über das Reich in ein eher feindseliges, von Mißtrauen und irrationalen Befürchtungen bestimmtes Urteil setzte gegen Ende der achtziger Jahre ein. Die törichte deutsche Kolonialpolitik, der Thronwechsel und die Entlassung Bismarcks waren dafür wichtige Gründe. Der Umschlag im Urteil verstärkte sich seit der unglückseligen Krügerdepesche von 1896 und mit Beginn der deutschen Flottenrüstung. Die Belege für die sich ändernde Sicht des Reiches in Großbritannien sind Legion. Das Reich, mit dem rhetorisch so unglücklich agierenden jungen Kaiser an seiner Spitze, wurde nun als Emporkömmling gesehen, als Herausforderer der etablierten Weltmacht. Rückblickend schrieb der Politiker Lord George Hamilton über die Jahre nach der Ablösung Bismarcks: „From the moment we gave up Heligoland, the whole tone of the German Government changed. It became aggressive, hostile and insincere, and from that time up to now I cannot recollect a simple instance in which Germany has behaved to us with either the courtesy or consideration which we undoubtedly received from other big countries in our international dealings ... Germany had suddenly sprung into wealth, and she had all the sensitiveness of the parvenu. “42 Für James Garvin, den Herausgeber der Zeitschrift The Outlook, war das Reich nach der Jahrhundertwende „no longer the saturated power of Bismarck's post-bellum reassurances“. Es war für ihn nun „an unsated Power“ und „a cause of intensifying anxiety and apprehension to all her neighbours « ${ }^{43}$.

In die britischen Urteile über das Reich flossen immer stärker Spott ein, Gereiztheit, Herablassung und Kritik an seiner innenpolitischen Struktur, ja verfassungsrechtlichen Rückständigkeit. Der schon zitierte James Garvin stellte 1906 fest: „In Germany ... the people have nothing to do with the conduct of foreign affairs. That is a matter that lies entirely in the hands of the Kaiser and of the Chancellor whom he appoints and dismisses at will. The Reichstag may discuss, but it cannot decide, what is to be Germany's policy towards England or any other country. It exercises no con-

40 Alfred Francis Pribram, England and the International Policy of the European Great Powers 1871-1914 (Oxford 1931) 10.

${ }^{41}$ Zit. in: Klaus Hildebrand, Von der Reichseinigung zur „Krieg-in-Sicht“-Krise. PreußenDeutschland als Faktor der britischen Außenpolitik 1866-1875, in: Michael Stürmer (Hrsg.), Das kaiserliche Deutschland. Politik und Gesellschaft 1870-1918 (Düsseldorf 1970) 227.

42 George F. Hamilton, Parliamentary Reminiscences and Reflections, Bd. 2: 1886-1906 (London 1922) 142. Dazu auch Rainer Labme, Großbritannien und die Anfänge des Neuen Kurses in Deutschland, in: Adolf M. Birke, Marie-Luise Recker (Hrsg.), Das gestörte Gleichgewicht. Deutschland als Problem britischer Sicherheit im neunzehnten und zwanzigsten Jahrhundert (München 1990) 65-80.

43 James Garvin, The Imprisoned Empire, in: The Outlook, 10. 3. 1906, 327. 
trol over the Chancellor, who is the instrument of a personal, dynastic and absolutist policy. Nothing it can say or do can affect the decisions or modify the course of action determined upon by the Emperor and his irresponsible advisers ... Until, therefore, Germany becomes a selfgoverning nation or England relapses into an autocracy, very different values must be attached to the flow of public opinion in the two countries. " ${ }^{\text {"4 }}$ Dabei übersah man in Großbritannien natürlich nicht, daß gerade bürgerliche und liberale Kräfte das Wilhelminische Reich auf den Weg der Weltmacht- und Flottenpolitik brachten. Indes, bei allem Antagonismus im deutsch-britischen Verhältnis dieser Jahre blieb das britische Urteil über das Reich und seine Führung ambivalent und Schwankungen unterworfen. Als Partner, um die politischen Ambitionen Frankreichs und Rußlands in Asien und Afrika, aber auch auf dem europäischen Kontinent zu zügeln, war das Reich ungeachtet aller britisch-deutschen Friktionen weiterhin geschätzt. „Solange England dem allgemeinen Grundsatz der Aufrechterhaltung des Gleichgewichts der Macht treu bleibt," schrieb der Abteilungsleiter im Foreign Office Sir Eyre Crowe Anfang 1907 in seinem berühmten Memorandum, ,wäre seinen Interessen nicht damit gedient, wenn Deutschland auf den Rang einer schwachen Macht herabgedrückt würde, da dies leicht zu einem französisch-russischen Übergewicht führen könnte, das für das britische Reich ebenso furchtbar, wenn nicht noch furchtbarer wäre. Es gibt keine bestehenden territorialen oder sonstigen deutschen Rechte, die England vermindert zu sehen wünschen könnte. Solange die Aktion Deutschlands daher die Grenze eines berechtigten Schutzes bestehender Rechte nicht überschreitet, kann es immer auf die Sympathie und das Wohlwollen, ja sogar auf die moralische Unterstützung Englands rechnen. “đs

Der Kaiser wurde belächelt. Sein Temperament und seine Sprunghaftigkeit lösten gelegentlich Verwunderung und Ärger aus; doch bei Besuchen in England wurde er von den Londonern umjubelt ${ }^{46}$. Daß Wilhelm II. einen Krieg gegen das Land seiner Vorfahren mütterlicherseits in Erwāgung ziehen könnte, unterstellte ihm in Großbritannien wohl niemand. Und auch Wilhelms Onkel Eduard VII. hielt einen Krieg zwischen beiden Ländern für völlig ausgeschlossen. Von Lord Esher, dem Freund des Monarchen, ist überliefert, daß der König einen militärischen Sieg Großbritanniens oder Deutschlands über den anderen als ein Desaster für beide Nationen bewertete ${ }^{47}$. Das Vertrauen in die prinzipielle Friedfertigkeit der Berliner Politik war durch die

\$4 Ders., The Sentimental Peril in Foreign Policy, in: The Outlook (20. 1. 1906) 81 f. Zur britischen Kritik am „Bismarckismus“ siehe vor allem Klaus Hildebrand, Zwischen Allianz und Antagonismus. Das Problem bilateraler Normalitāt in den britisch-deutschen Beziehungen des 19. Jahrhunderts (1870-1914), in: Heinz Dollinger u.a. (Hrsg.), Weltpolitik, Europagedanke, Regionalismus. Festschrift für Heinz Gollwitzer zum 65. Geburtstag am 30. Januar 1982 (Münster 1982) 305-331. Zur Haltung der britischen Linken: Friedrich Weckerlein, Streitfall Deutschland. Die britische Linke und die „Demokratisierung" des deutschen Reiches, 1900-1918 (Göttingen und Zürich 1994).

4s Die Britischen Amtlichen Dokumente über den Ursprung des Weltkrieges 1898-1914, Bd. 3 (Stuttgart 1929) 681.

${ }_{46}$ Zum Bild Wilhelms II. in der britischen Öffentlichkeit bereitet Lothar Reinermann (Köln) eine Studie vor.

${ }^{47}$ Reginal B. Brett (Viscount Esher), The Influence of King Edward and Essays on Other Subjects (London 1915) 55. 
dröhnende Rhetorik des Kaisers und deutscher Politiker noch nicht zerstört. Selbst ein so mißtrauischer Mann wie Winston Churchill, damals Marineminister, schrieb im Mai 1912 an den deutschstämmigen Finanzier Sir Ernest Cassel: „I have never had any but friendly feelings towards that great nation ... and I regard the antagonism which has developed as insensate. Anything in my power to terminate it, I would gladly do. ${ }^{448}$

In mancher Hinsicht hat der Erste Weltkrieg die dunklen Ahnungen Eduards VII. über die Konsequenzen eines deutsch-britischen Konfliktes bestätigt. Nach 1918 ebneten dann aber ganz wesentlich zwei Faktoren Großbritannien den Weg zu einer Wiederannäherung an den ehemaligen Kriegsgegner. Der eine Faktor war das damals schon geläufige Konstrukt einer Zwei-Deutschland-Theorie, die mit ihrer etwas naiven Unterscheidung zwischen dem schlechten, durch preußischen Einfluß verbildeten Deutschland und dem guten, kulturell-wissenschaftlich bedeutenden Deutschland den Briten Anknüpfungspunkte für eine Aussöhnung und eine Revision des Urteils über das Reich der demokratischen Weimarer Republik bot. Die Theorie wirkte bekanntlich bis in die ersten Jahre des Zweiten Weltkrieges nach, als man in Großbritannien immer noch geneigt war, zwischen Hitler und dem „anderen Deutschland“, den Nationalsozialisten und dem deutschen Volk einen Unterschied zu machen ${ }^{49}$. Interessant ist der Umstand, daß sich nach 1918 die pro- und antideutsche Haltung in Großbritannien entlang ideologischer bzw. parteipolitischer Bruchlinien orientierte. Auf dem linken und radikalliberalen Ende des politischen Spektrums in Großbritannien überwog ungeachtet mancher Bedenken die Neigung, die deutsche Sozialdemokratie als Teil des „guten“ Deutschland anzusehen und so die Weimarer Republik als demokratischen Neuanfang zu akzeptieren ${ }^{50}$. „If Germany had had a democracy ... like ourselves ...“, meinte Lloyd George schon im März 1917, „we should not have had this trouble. " 51 Die politische Rechte hielt demgegenüber an der Position fest, Deutschland sei identisch mit Preußen, mit reaktionärem Junkertum, mit Militarismus und ungehemmtem Expansionswillen. Von der Verlegenheitskonstruktion der demokratischen Republik werde dies nur notdürftig kaschiert.

Erhebliche Bedeutung für die deutschen Revisionsbestrebungen nach dem Versailler Frieden und das Verhältnis zu Großbritannien gewann eine dritte, mittlere Position gegenüber dem Reich, die der linke Flügel der Konservativen, die Liberalen und

48 Zit. nach Richard Hough, Former Naval Person. Churchill and the Wars at Sea (London 1985) 51. Siehe auch Jobn A.S. Grenville, Imperial Germany and Britain: From cooperation to war, in: Birke, Recker (Hrsg.), Das gestörte Gleichgewicht, 90.

49 Lothar Kettenacker (Hrsg.), Das „Andere Deutschland“ im Zweiten Weltkrieg. Emigration und Widerstand in internationaler Perspektive (Stuttgart 1977). Zu den Ursprüngen der ZweiDeutschland-Theorie vgl. Wolf $D$. Gruner, Vom Deutschen Bund zum Deutschen Reich. Aspekte eines britischen Deutschlandbildes vor der Reichsgründung, in: Wendt (Hrsg.), Das britische Deutschlandbild, 55-78, und Joacbim Kuropka, „Militarismus“ und das „Andere Deutschland“. Zur Entstehung eines Musters britischer Deutschlandinterpretation, in: ebd., 103-124.

so Reinbard Meyers, Das Dritte Reich in britischer Sicht. Grundzüge und Determinanten britischer Deutschlandbilder in den dreißiger Jahren, in: Wendt (Hrsg.), Das britische Deutschlandbild, 133.

${ }^{11}$ Zit. in: David Reynolds, Great Britain and the Third Reich, 1933-1940. Appeasement, Intelligence and Misperception, in: Birke, Recker (Hrsg.), Das gestörte Gleichgewicht, 118. 
die Gemāßigten in der Labour Party vertraten. Vertreter dieser Position betrachteten den Versailler Vertrag nicht als ein für alle Zeit gültiges, in sich geschlossenes Vertragswerk. Sie erkannten Deutschlands „legitimate grievances“ und Wunsch nach einer Revision der Vertragsbestimmungen an. Die Politik, in diesen Fragen den Deutschen entgegenzukommen, stieß bei den Vertretern dieser mittleren Position auf Verständnis und Unterstützung. Stellvertretend soll hier Lord Riddell zitiert werden, ein enger Vertrauter des Premierministers David Lloyd George. Schon im April 1920 notierte Lord Riddell: „The official British point of view is that the German nation were not responsible for the war, that the Junkers have been ejected, that the German Government should be supported, that the German industries should be revived and that, generally, the Germans should not be regarded with suspicion." ${ }^{\text {i2 }}$

$\mathrm{Da}$ s sich für Großbritannien - vor allem langfristig gesehen - Möglichkeiten für eine Wiederannäherung an das Reich ergaben, war mithin weniger ein Produkt von Germanophilie denn Ergebnis nüchternen politischen Kalküls. Damit ist der zweite Faktor angesprochen, der den Briten den Weg zu einem Ausgleich mit dem ehemaligen Kriegsgegner ebnen half. Das Streben nach Ausgleich war Ausdruck des britischen Wunsches, Deutschland im Schatten des revolutionären Sowjetrußland als antikommunistisches Bollwerk zu stärken, und der Einsicht, daß Europa möglichst rasch aus der Kriegssituation in ein auf Kooperation und Verhandlungen basierendes Staatensystem überführt werden mußte, in dem Deutschland ein Partner war. Früher Ausfluß der einschlägigen Überlegungen auf britischer Seite war das bekannte Fontainebleau-Memorandum Lloyd Georges vom März 1919. In ihm wurden nicht nur die Bedingungen für die Sicherung eines dauerhaften Friedens niedergelegt, sondern wurde auch vor einem Sieg der kommunistischen Weltrevolution in Deutschland gewarnt ${ }^{53}$. Die im Memorandum genannten Ziele britischer Europa- und Deutschlandpolitik waren aber nur realisierbar, wenn der Krieg nicht mit anderen Mitteln fortgeführt und seine Ergebnisse nicht auf Dauer festgeschrieben wurden, wie es Frankreich in seinem übersteigerten Sicherheitsbedürfnis damals zu tun versuchte.

Das seit 1914 dominierende harsche Urteil über das Reich und seine kriegslüsterne Politik wurde in Großbritannien nach 1918 auch dadurch abgemildert, daß sich die Rahmenbedingungen britischer Außenpolitik fundamental geändert hatten. Niemals zuvor hatte das Empire einen solchen territorialen Umfang wie nach der Übergabe deutscher Kolonien und ehemals osmanischer Gebiete in die Obhut der britischen Mandatsverwaltung. Und niemals zuvor hatte ein deutlicher politischer und wirtschaftlicher Machtverlust Großbritannien in eine so augenfällige Situation der strategischen Überbeanspruchung gebracht. Da Deutschland als politischer Rivale und Herausforderer für längere Zeit ausgeschaltet schien, verschwanden aus der britischen Haltung zum Weimarer Deutschland die Emotionen. Eine kühlere Sicht gewann wieder die Oberhand. Einen Tag nach Unterzeichnung des Versailler Friedensvertrages

\footnotetext{
52 Lord Riddell's Intimate Diary of the Peace Conference and After 1918-1923 (London 1933) 188. Dazu ausführlich Gottfried Niedbart, Multipolares Gleichgewicht und weltwirtschaftliche Verflechtung: Deutschland in der britischen Appeasement-Politik 1919-1933, in: Michael Stürmer (Hrsg.), Die Weimarer Republik. Belagerte Civitas (Königstein/Ts. 1980) 113-130.

53 David Lloyd George, The Truth about the Peace Treaties, Bd. 1 (London 1938) $404 \mathrm{ff}$.
} 
schrieb der spätere Außenminister Austen Chamberlain: „If Germany remains or becomes really democratic, they cannot repeat the folly of Frederic the Great and Bismarck and his later followers. No democracy can or will make aggressive war its yearlong study and business. “54 Für Lloyd George, den Premierminister, gab es keinen Zweifel, daß "Germany is to us the most important country in Europe“55.

In gewisser Weise knüpfte die Londoner Politik nach dem Ersten Weltkrieg an der Einstellung wieder an, die sie gegenüber dem Reich in den knapp zwei Jahrzehnten nach 1871 eingenommen hatte. Im Hinblick auf Europa formulierte London eine Politik, die in den zwanziger und frühen dreißiger Jahren auf Erhalt des Friedens, Behebung der Kriegsfolgen und die Stabilisierung einer liberalen Wirtschaftsordnung abzielte $^{56}$. Die Methode zur Erreichung dieses Ziels, gerade auch im Hinblick auf Deutschland, hieß Appeasement - ein Begriff, der in den zwanziger Jahren im britischen Verständnis noch ganz positiv besetzt war. Nicht zu übersehen ist allerdings, daß das britische Interesse an Deutschland nach dem Friedensschluß rasch nachließ. Marie-Luise Recker hat zu Recht darauf hingewiesen, daß „das Bild der Weimarer Republik in Großbritannien unscharf und widersprüchlich“ blieb. „Der demokratische Neuanfang in Berlin wurde zwar begrüßt, der Wille zu neuen politischen Akzenten bei den Parteien der Mitte und der gemäßigten Linken auch positiv vermerkt, doch gab es nach wie vor Zweifel an der Dauerhaftigkeit und Stärke dieses Wandels... Auch das außenpolitische Verhalten der Weimarer Regierungen nährte diese Unsicherheit.“ Die deutschen Revisionsforderungen trafen auf Sympathie, doch „die Art und Weise, in der diese Forderungen erhoben wurden, und auch das mangelnde Entgegenkommen gegenüber Anregungen und Forderungen der Alliierten [stießen] immer wieder auf Mißtrauen und Mißbilligung “57. Dennoch war im Foreign Office Anfang der dreißiger Jahre nicht umstritten, daß Großbritannien dem Reich erlauben müsse, „to resume her place and rights as a great power on equal footing with the others ${ }^{458}$.

Problematisch für die britische Europapolitik der dreißiger Jahre sollte das Faktum werden, daß die in den frühen zwanziger Jahren festgelegten Leitlinien dieser Politik, die Haltung und Politik gegenüber Deutschland eingeschlossen, nicht oder nicht schnell genug den veränderten Umständen angepaßt wurden. Der Blick blieb, wie es Lothar Kettenacker einmal formuliert hat, „starr auf die Kontinuitätsmerkmale der deutschen Geschichte“ gerichtet, das "qualitativ Neue der Hitlerbewegung“ wurde nicht wahrgenommen ${ }^{59}$. Das galt vor allem für die ersten Monate und Jahre nach der

54 Zit. in: Recker, Demokratische Neuordnung, 101.

${ }_{55}$ Zit. in: C.J. Lowe, Micbael L. Dockrill, The Mirage of Power, Bd. 2 (London 1972) 356.

s6 Vgl. dazu immer noch Bernd-Jürgen Wendt, Economic Appeasement. Handel und Finanz in der britischen Deutschland-Politik 1933-1939 (Düsseldorf 1971); ders, Die englische Politik des Appeasement in den dreißiger Jahren und ihre Beurteilung in der Geschichtswissenschaft, in: Gerbard Schulz (Hrsg.), Die Große Krise der dreißiger Jahre. Vom Niedergang der Weltwirtschaft zum Zweiten Weltkrieg (Göttingen 1985) 233-260; außerdem Recker, Demokratische Neuordnung, 97-112; Bernd Dobrmann, Die englische Europapolitik in der Wirtschaftskrise 19211923. Zur Interdependenz von Wirtschaftsinteressen und Außenpolitik (München, Wien 1980).

57 Recker, Demokratische Neuordnung, 110.

s8 So Alexander Cadogan im Mai 1932 (zit. in: Reynolds, Great Britain and the Third Reich, 119).

59 Lothar Kettenacker, Preußen-Deutschland als britisches Feindbild im Zweiten Weltkrieg, in: 
nationalsozialistischen „Machtergreifung“, als sich selbst ein so guter Deutschlandkenner wie Harold Nicolson für die politische Entwicklung im Reich nur beiläufig interessierte $^{60}$. Die mangelnde Fähigkeit, einmal verfestigte Urteile, Beurteilungen und Einstellungen schnell zu modifizieren, führte bei der politischen Elite Großbritanniens anfänglich zu einer Fehleinschätzung, genauer: zur Unterschätzung Hitlers und des sogenannten Dritten Reiches ${ }^{61}$. Vom Vorwurf, Hitler und den Nationalsozialismus lange Zeit unterschätzt zu haben, können auch Männer wie Winston Churchill oder Sir Robert Vansittart nicht freigesprochen werden. Ihr Urteil über das nationalsozialistische Regime beruhte nicht auf einer direkten und persönlichen Kenntnis der Verhältnisse in Deutschland nach dem Einschnitt von 1933. Churchill war weder ein Kritiker Hitler-Deutschlands vom Tag der Machtübernahme an, wie etwa Dietrich Aigner nachweist ${ }^{62}$, noch beruhte seine Kritik von Anfang an auf selbstgewonnenen Einsichten in die Mechanismen und Hintergründe des nationalsozialistischen Regimes.

Im Gegensatz zu den Äußerungen in seinem Memoirenband The Gathering Storm (1948), wo Churchill die Nachwelt davon überzeugen möchte, daß er schon in den zwanziger Jahren die „deutsche Gefahr" in den Mittelpunkt seiner politischen Aktivitäten gestellt habe, trat er eigentlich erst ab 1935 als entschiedener Gegner jeglicher Zugeständnisse an Nazi-Deutschland auf, als einer der heftigsten Kritiker der britischen Appeasement-Politik. Noch im November 1935 nannte er Hitler in dem schon zitierten Zeitschriftenartikel „The Truth about Hitler" ein „mystery“. Churchill schloß zum damaligen Zeitpunkt die Möglichkeit nicht aus, daß sich Hitler als Retter der Deutschen entpuppen könnte - as „the man who restored honour and peace of mind to the great Germanic nation and brought them back secure, helpful and strong, to the European family circle“. Allein die Zukunft werde entscheiden, „whether he will rank in Valhalla with Pericles, with Augustus, and with Washington, or whether in the inferno of human scorn with Attila and Tamerlane. It is enough to say that both possibilities are open at the present moment. ${ }^{\text {"63 }}$ Wie Sebastian Haffner und Dietrich Aigner in ihren Churchill-Biographien richtig beobachten, rutschte Churchill in seine entschlossene Gegnerschaft zu Hitler und Nazi-Deutschland erst relativ spät mehr oder weniger hinein ${ }^{64}$. Der bestürzende Antisemitismus, der innenpolitische Terror des Regimes und die Bekanntschaft mit Vansittart waren dafür Auslöser.

Gerade Churchill ist als Verkörperung der zunächst deutschlandkritischen und

\section{Fortsetzung Fußnote von Seite 174}

Wendt (Hrsg.), Das britische Deutschlandbild, 146; Reynolds, Great Britain and the Third Reich, 118 und 127; Bußmann, Maßstäbe; Oswald Hauser, England und das Dritte Reich, 2 Bde. (Göttingen, Zürich 1982).

60 Hermann Fromm, Das Dritte Reich im Urteil eines Engländers: Harold Nicholson und die Deutschen 1933-1945, in: Kettenacker u.a. (Hrsg.), Studien zur Geschichte Englands, 246.

${ }^{61}$ Hierzu vor allem Niedhart, Zwischen negativem Deutschlandbild und Primat des Friedens.

62 Dietrich Aigner, Das Ringen um England. Das deutsch-britische Verhältnis. Die öffentliche Meinung 1933-1939. Tragödie zweier Völker (München 1969) 154 f.

63 Churchill, Truth about Hitler, $10 \mathrm{f}$.

64 Sebastian Haffner, Winston Churchill in Selbstzeugnissen und Bilddokumenten (Reinbek 1967) 96; Dietrich Aigner, Winston Churchill. Ruhm und Legende (Göttingen 1975) 102-122. 
dann deutschfeindlichen Komponente im britischen Urteil ein gutes Beispiel dafür, daß die Gegner des Nationalsozialismus sich in ihrer Deutung Hitler-Deutschlands nur schwer vom überlieferten Deutschlandbild trennen konnten. Das prinzipiell Neue und Gefährliche in der nationalsozialistischen Ideologie und Politik entging ihnen lange Zeit, ungeachtet des zunehmenden Interesses vieler Briten am nationalsozialistischen Reich ${ }^{65}$. Zwar mißtraute Neville Chamberlain dem deutschen Diktator, aber, so meinte er selbst noch im März 1939, die britische Politik sei „still the same, namely, the securing of peace by the removal of reasonable causes of war, whilst pursuing a programme of rearmament ${ }^{* 66}$. Dennoch, das ,amtliche" britische Urteil über das nationalsozialistische Reich stand spätestens seit Mitte 1936 fest: „Hitler's foreign policy may be summed up as the destruction of the peace settlement and reestablishment of Germany as the dominant Power in Europe."67 Vansittart, als Unterstaatssekretär praktisch der Chef des Londoner Foreign Office, warnte vom Beginn der nationalsozialistischen "Machtergreifung“ an vor der Kriegsgefahr, die von Deutschland wieder ausgehe. In den dreißiger Jahren war aber selbst Vansittart kein kategorischer Gegner von Zugeständnissen an das Reich, wiewohl eine langfristig angelegte Revision des Versailler Vertrags für ihn nur in einem gesamteuropäischen Rahmen in Frage kam ${ }^{68}$.

Vansittarts Ruf als unerbittlicher „Deutschenhasser“ und entschiedener Gegner des nationalsozialistischen Reiches entstammt der Zeit, als er, nach seiner Ablösung im Januar 1938 durch Sir Alexander Cadogan, seine politischen Ansichten in Zeitungsartikeln, Pamphleten und Rundfunkansprachen ungehindert vertreten konnte. Vansittarts Black Record. Germans Past and Present, Ende 1940 in der Form von Vorträgen von der BBC gesendet und im Januar 1941 als Pamphlet erschienen, bildete den Anfang seiner Laufbahn als Publizist deutschfeindlicher Schriften. Das Pamphlet war in Großbritannien Auslöser einer kontroversen, mit viel Polemik geführten Diskussion um die Frage nach der richtigen Interpretation Hitler-Deutschlands ${ }^{69}$. In dem Bemühen zu erklären, warum Preußen/Deutschland Europa innerhalb von nur 75 Jahren in fünf Kriege gestürzt hatte, projizierte Vansittart ein übersteigertes Bild nationalsozialistischer Gegenwart auf die deutsche Geschichte der letzten zweitausend Jahre. In dieser Geschichte bezeichnete für ihn das Deutsche Reich während dessen kurzen Existenz den Tiefpunkt. Mit dieser zeitgebundenen Sicht der deutschen Geschichte und des Reiches war Vansittart in Großbritannien damals wahrlich kein Außenseiter. Auch das Foreign Office und Briten, die es eigentlich besser hätten wissen müssen, schlossen sich der pauschalen Verdammnis Deutschlands an ${ }^{70}$. Wer wollte sie dafür kritisieren!

${ }^{65}$ Vgl. Reynolds, Great Britain and the Third Reich, 119, und die ausgezeichnete Studie von Schwarz, Reise.

${ }^{66}$ Zit. in: Reynolds, 127.

67 Memorandum Anthony Edens „The German Danger“, 17. 9. 1936 (Documents on British Foreign Policy 1919-1939, 2. Serie, Bd. 15 [London 1976] 569).

${ }^{68}$ Vgl. Klaus Jaitner, Aspekte britischer Deutschlandpolitik 1930-32, in: Josef Becker, Klaus Hildebrand (Hrsg.), Internationale Beziehungen in der Weltwirtschaftskrise 1929-1933 (München 1980) 21-38.

69 Vgl. Schwarz, Reise, 70 und Norman Rose, Vansittart: Study of a Diplomat (London 1978).

${ }^{70}$ Kettenacker, Preußen-Deutschland als britisches Feindbild, 145-168. 
Das britische Urteil über das Deutsche Reich hatte damit zum zweitenmal in unserem Jahrhundert eine extreme, von starken Emotionen beherrschte Position erreicht, und das aus sehr verständlichen Gründen. Nach 1945, vor allem dann in den fünfziger Jahren, schlug das Pendel zurück. Man mag hoffen, daß die Mittellage, die es seitdem erreicht hat, lange Bestand haben wird. 
